\title{
PARTISIPASI ANGGOTA PADA KELOMPOK TANI SUSURIPEN DI KELURAHAN WAILAN KECAMATAN TOMOHON UTARA KOTA TOMOHON
}

\author{
Esti Fanny Pentury \\ Jenny Baroleh \\ Welson M. Wangke
}

\begin{abstract}
ABSRACT
This research has purpose to find out participation of susuripen farmer group's member in the wailan sub district, north tomohon district, tomohon city. This research been carried out for three months, from April 2016 to June 2016, start from preparation until the prepration of reports. Data used in this research is primary data and secondary data. Primary data obtained from direct interview to the respodents with using questionnaires and secondary data obtained from government agencies which related to the location. Sampling technique used census method with the total of Susuripen farmer groups member is 20 people been interviewed with the questionnaires. Data analysis in this research used descriptive analysis and also likert scale, with level 1 (less active), 2 (active), 3 (very active). This research found based on the analysis using likert scale, that total index of member participation in the Susuripen farmer groups in decision making phase which cover the activeness in the meeting attendance and activeness in the giving opininon. Member participation in the realization activity which covers, activeness in the rice paddy cultivation, activeness in the Horticulture cultivation, activeness in the rice paddy harvest and postharvest, activeness in the agricultural extension attendance, activeness in the mandatory contribution. Member participation in the evaluation phase which covers involvement in monitoring groups' activity, involvement in calculating agribusiness outputs. With 79,8 categorized high. Further analysis shows that the member participation level in Susuripen farmer groups with score 479 from presumption that highest score is 600 and lowest score 200. Suggestion in this research based on the summary for the government or locals is motivate member participation in Susuripen farmer groups in the Wailan sub district, north Tomohon district, Tomohon city because that is the main key and main business in the food security development.
\end{abstract}

Key word: participation, farmer group, Wailan, Tomohon

\begin{abstract}
ABSTRAK
Penelitian ini bertujuan untuk mengetahui partisipasi anggota pada kelompok tani susuripen di kelurahan wailan, kecamatan tomohon utara, kota tomohon. Penelitian ini berlangsung selama 3 bulan, yaitu bulan april 2016 hingga juni 2016, mulai dari persiapan hingga penyusunan laporan penelitian. Data yang digunakan dalam penelitian ini adalah data primer dan data sekunder. Data primer diperoleh melalui wawancara langsung kepada responden dengan menggunakan kuesioner dan data sekunder diperoleh melalui instansi pemeritah yang terkait dengan lokasi penelitian. Teknik pengumpulan data menggunakan teknik sensus yaitu semua anggota kelompok Tani Susuripen berjumlah 20 orang diwawancarai dengan menggunakan kuesioner. Analisis data dalam penelitian in menggunakan analisis deskriptif dan juga menggunakan Skala Likert, dengan level 1 (kurang aktif), 2 (aktif), 3 (sangat aktif). Hasil penelitian ini menemukan berdasarkan analisis menggunakan Skala Likert, bahwa jumlah indeks partisipasi anggota pada kelompok tani susuripen dalam tahap pembentukan keputusan yang didalamnya mencakup, keaktifan dalam mengikuti pertemuan dan keaktifan dalam memberikan masukan. Partisipasi anggota pada dalam pelaksanaan kegiatan yang didalamnya mencakup, keaktifan dalam penanaman padi sawah, keaktifan dalam penanaman tanaman hortikultura, keaktifan dalam panen dan pasca panen padi sawah, kealtifan dalam panen hingga pasca panen tanaman hortikultura, keaktifan dalam mengikuti penyuluhan, keaktifan dalam memberikan iuran wajib. Partisipasi anggota dalam tahap evaluasi yang didalamnya mencakup keterlibatan dalam pemantauan kegiatan kelompok, keterlibatan dalam mengukur berbagai hasil kegiatan usaha tani. Berada pada 79,8 sehingga tergolong tinggi. Analisis lebih lanjut menunjukkan bahwa tingkat partisipasi anggota pada kelompok tani susuripen pada skor 479 dari kisaran jumlah yang ideal mencetak skor tertinggi adalah 600 dan skor terendah adalah 200. Saran dalam penelitian ini adalah, berdasarkan pada kesimpulan yang diperoleh, adalah pemerintah maupun masyarakat setempat lebih mengiatkan partisipasi anggota pada kelompok tani Susuripen di Kelurahan Wailan Kecamatan Tomohon Utara Kota Tomohon karena hal tersebut merupakan pelaku utama dan pelaku usaha dalam pembangunan ketahanan pangan.
\end{abstract}

Kata kunci: partisipasi, kelompok tani, Wailan, Tomohon 


\section{PENDAHULUAN}

\section{Latar belakang}

Negara Kesatuan Republik Indonesia memiliki ribuan pulau dengan tanah yang amat subur dan sangat kaya dengan hasil alamnya sehingga sangat cocok untuk bercocok tanam. Sumber Daya Manusia mempunyai peranan yang sangat penting dalam pembangunan. Sumber daya manusia yang memiliki jiwa sosial yang tinggi akan mampu meningkatkan produktivitas kelompok tani melalui partisipasi yang diberikan. Partisipasi memang bukanlah sesuatu yang baru yang kita lihat, dengar bahkan dilakukan dalam berbagai kegiatan yang bertujuan untuk membangun baik dari tingkat propinsi, kota, kelurahan maupun desa, suatu pembangunan dan pengembangan hasil pembangunan tidak akan berhasil tanpa adanya partisipasi.

Partisipasi anggota atau partisipasi petani merupakan keikutsertaan dari petani baik secara individu maupun secara kelompok dengan penuh kesadaran dan tanggung jawab dalam bidang usaha pertanian. Partisipasi merupakan faktor yang sangat penting dalam melaksanakan berbagai aktivitas ataupun program pertanian. Partisipasi tersebut dapat berupa partisipasi dalam tahap pembentukan keputusan, partisipasi dalam tahap pelaksanaan, partisipasi partisipasi dalam tahap evaluasi.

Kelembagaan dalam pengertian ilmu sosial tidak semata-mata lembaga atau instansi atau organisasi yang memliki struktur saja, namun juga meliputi seperangkat tatanan norma dalam kehidupan bermasyarakat guna mencapai tujuan tertentu Soekanto (2003) dalam Amanah dan Farmayanti (2014). Pengertian kelembagaan juga mencakup kegiatan sistem gotong royong, sistem sakap dan bagi hasil, dan sebagainya, yang merupakan aktifitas kolektif masyarakat yang memiliki kelengkapan norma atau aturan tak tertulis yang dipahami dan disepakati oleh para pelakunya. Dalam uraian ini yang dimaksud dengan kelembagaan dibatasi sebagai suatu organisasi yang memiliki struktur tegas. Sebagai contoh adalah kelompok tani yang secara struktural memiliki kepengurusan berupa ketua, sekertaris, bendahara dan anggota, serta memiliki aturanaturan keorganisasian. Nuryanti dan swastika (2011), dijelaskan bahwa secara umum, kelompok tani dibentuk untuk memecahkan permasalahan yang dihadapi petani yang tidak bisa diatasi secara individu, kelompok tani dapat dibentuk secara swadaya maupun atas dasar kepentingan kebijakan dari pemerintah melalui Dinas Pertanian.

Kelompok Tani Susuripen merupakan salah satu kelompok tani yang aktif dari beberapa kelompok tani di Kelurahan Wailan Susuripen merupakan bahasa tombulu yang memiliki arti "kebun yang agak kedalam atau kebun yang tersembunyi". Kelompok tani Susuripen beranggotakan 20 orang dan di koordinir oleh ketua kelompok dengan luas lahan padi sawah yang di kelolah sebesar $20 \mathrm{Ha}$ dan luas lahan tanaman hortikultura sebesar 1,5 Ha. Kelompok Tani Susuripen terbentuk pada bulan Agustus 2004 hingga 2016, Kelompok Tani Susuripen selalu aktif dalam kegiatan kelompoknya hal ini di karenakan oleh budaya mapalus atau budaya gotong royong yang sangat tinggi yang ditanamkan oleh para anggota di dalam kelompok. Ketua dari kelompok tani Susuripen merupakan petani yang mampu mengerakan seluruh anggotanya untuk selalu aktif dalam berbagai kegiatan yang dikarenakan oleh kelompok tani.

Usaha meningkatkan kesejahteraan petani dan ketahanan pangan, peran kelembagaan kelompok tani dan partisipasi anggota sangat penting dalam mendukung dan melaksanakan berbagai program yang sedang dan akan dilaksanakan oleh kelompok tani. Hal inilah yang membuat penulis tertarik untuk mengangkat judul ini, serta penulis juga ingin mencari tahu bagaimana partisipasi anggota secara spesifik pada kelompok tani susuripen karena hal tersebut merupakan pelaku utama dan pelaku usaha dalam pembangunan ketahanan pangan.

\section{Tujuan}

Penelitian ini bertujuan untuk mengetahui partisipasi anggota pada Kelompok Tani Susuripen.

\section{Manfaat}

1. Memberikan informasi dan gambaran tentang partisipasi anggota pada kelompok tani Susuripen.

2. Sebagai bahan pertimbangan bagi pemerintah dan instansi terkait untuk pengembangan kelompok tani pada umumnya. 


\section{METODOLOGI PENELITIAN}

\section{Waktu dan Tempat Penelitian}

Penelitian ini dilaksanakan selama 3 bulan mulai dari bulan April sampai dengan bulan Juni 2016, mulai dari persiapan sampai dengan penyusunan laporan hasil penelitian. Tempat penelitian ini dilaksanakan di Kelurahan Wailan, Kecamatan Tomohon Utara, Kota Tomohon.

\section{Jenis dan Sumber Data}

Jenis dan sumber data dalam penelitian ini sebagai berikut:

1. Data primer diperoleh melalui wawancara langsung kepada responden dengan menggunakan kuesioner yang telah disiapkan.

2. Data sekunder diperoleh dari instansi pemerintah yang terkait dengan lokasi penelitian.

\section{Teknik Pengumpulan Data}

Teknik yang digunakan dalam mengumpulkan data adalah menggunakan teknik sensus yaitu semua anggota Kelompok Tani Susuripen berjumlah 20 orang merupakan responden, sehingga semua anggota diwawancarai denggan menggunakan kuesioner.

\section{Konsep Pengukuran Variabel}

Variabel dalam penelitian ini mencakup tingkat Partisipasi Anggota yakni sebagai berikut:

\section{Karakteristik Responden}

a. Nama

b. Jenis Kelamin

c. Umur Responden dalam tahun

d. Tingkat Pendidikan adalah SD, SMP, SMA

2. Indikator Partisipasi Responden

A. Partisipasi dalam tahap pembentukan keputusan:

1. Keaktifan dalam mengikuti pertemuan.

a) Sangat Aktif (35-52 kali dalam setahun)

b) Aktif (18-34 kali dalam setahun)

c) Kurang Aktif (1-17 kali saja dalam setahun)

2. Keaktifan dalam memberikan masukan

a) Sangat Aktif (35-52 kali dalam setahun)

b) Aktif (18-34 kali dalam setahun) c) Kurang Aktif (1-17 kali saja dalam setahun)

B. Partisipasi dalam tahap pelaksanaan:

3. Keaktifan dalam penanaman padi sawah.

a. Sangat Aktif (1-2 kali dalam setahun)

b. Aktif (1 kali dalam setahun)

c. Kurang Aktif (kurang dari 1 kali dalam setahun)

4. Keaktifan dalam penanaman tanaman hortikultura.

a. Sangat Aktif (1-5 kali penanaman dalam setahun)

b. Aktif (3 kali penanaman dalam setahun)

c. Kurang Aktif (sekali penanaman dalam setahun)

5. Keaktifan dalam panen dan pasca panen padi sawah.

a. Sangat Aktif (1-2 kali dalam setahun)

b. Aktif (1 kali dalam setahun)

c. Kurang Aktif (kurang dari 1 kali dalam setahun)

6. Keaktifan dalam panen pasca panen tanaman hortikultura.

a. Sangat Aktif (1-41 kali panen dalam setahun)

b. Aktif (1-28 kali panen dalam setahun)

c. Kurang Aktif (1-13 kali panen dalam setahun)

7. Keaktifan dalam mengikuti penyuluhan.

a. Sangat Aktif (33-48 kali dalam setahun)

b. Aktif (17-32 kali dalam setahun)

c. Kurang Aktif (1-16 kali saja dalam setahun)

8. Keaktifan dalam memberikan iuran wajib.

a. Sangat Aktif (35-52 kali dalam setahun)

b. Aktif (18-34 kali dalam setahun)

c. Kurang Aktif (1-17 kali saja dalam setahun)

C. Partisipasi dalam tahap evaluasi:

9. Keterlibatan dalam pemantauan kegiatan kelompok.

a. Sangat Aktif (setiap hasil kegiatan kelompok selalu memberikan masukan dalam hasil yang diperoleh).

b. Aktif (hamip di setiap kegiatan kelompok selalu memberikan masukan).

c. Kurang Aktif (jarang memperhatikan dan memberikan masukan mengenai kegiatan kelompok)

10. Keterlibatan dalam mengukur berbagai hasil kegiatan usaha tani. 
a). Sangat Aktif (setiap hasil kegiatan usaha tani selalu memberikan masukan dalam hasil yang diperoleh).

b). Aktif (hampir di setiap hasil kegiatan usaha tani selalu memberikan masukan).

c). Kurang Aktif (jarang memperhatikan dan memberikan masukan mengenai berbagai hasil kegiatan usaha tani).

\section{Analisis Data}

Analisis data yang digunakan dalam penelitian ini adalah analisis deskriptif dengan menggunakan Skala likert, Skala Likert digunakan untuk mengukur partisipasi seseorang atau kelompok dalam skala likert, maka variabel yang di ukur dijabarkan menjadi indikator variabel. Kemudian indikator tersebut dijadikan sebagai titik tolak untuk menyusun item-item instrument yang dapat berupa pertanyaan-pertanyaan. Dalam penelitian ini di susun 10 (Sepuluh) pertanyaan dengan total responden 20 (dua puluh) orang. Jawaban setiap instrument yang menggunakan skala likert diungkapkan dengan kata- kata, berikut:

$$
\begin{aligned}
& \text { S3 }=\text { Sangat Aktif } \\
& \text { S2 }=\text { Aktif } \\
& \text { S1 }=\text { Kurang Aktif }
\end{aligned}
$$

Dengan cara perhitungan skor masing-masing pertanyaan:

Jumlah skor tiap kriteria = capaian skor $\mathrm{x}$ jumlah responden.

$$
\begin{aligned}
& \mathrm{S} 3=3 \times 20=60 \\
& \mathrm{~S} 2=2 \mathrm{X} 20=40 \\
& \mathrm{~S} 1=1 \mathrm{X} 20=20
\end{aligned}
$$

Jumlah skor ideal untuk setiap pernyataan (skor tertinggi) $=60$

Jumlah skor terendah $=20$

Dengan interprestasi nilai:

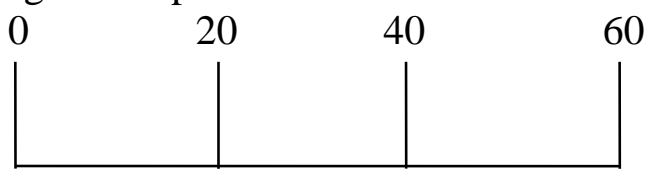

\section{Rendah Cukup Tinggi}

Cara perhitungan skor keseluruhan untuk mengetahui partisipasi anggota:

Jumlah skor seluruh kriterium = capaian jumlah skor $\mathrm{X}$ jumlah responden $\mathrm{X}$ instrumen pertanyaan

Untuk:

$\mathrm{S} 3=3 \times 20 \times 10=600$

$\mathrm{S} 2=2 \times 20 \times 10=400$
$\mathrm{S} 1=1 \mathrm{X} 20 \mathrm{X} 10=200$

Jumlah skor ideal untuk keseluruhan pertanyaan $=600$ (tinggi)

Jumlah skor rendah $=200$ (Rendah)

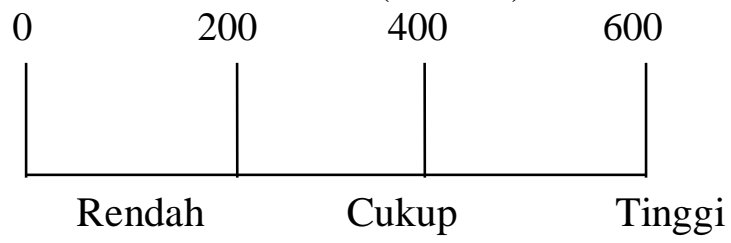

Tingkat Partisipasi Anggota $=$ Jumlah Skor Hasil Pengumpulan Data X 100\%.

Jumlah Skor Ideal (tertinggi)

Dengan interprestasi nilai:

$$
\begin{array}{ccc}
0 & 33,3 \% & 66,6 \% \\
100 \% &
\end{array}
$$

\section{Rendah Cukup Tinggi}

Keterangan kriteria inerprestasi skor partisipasi anggota:

Angka 0\%-33,3\% = Rendah

Angka 33,4\% - 66,6\%= Cukup

Angka $66,7 \%-100 \%=$ Tinggi

\section{HASIL DAN PEMBAHASAN}

\section{Deskripsi Wilayah Penelitian}

\section{Letak Geografis dan Iklim}

Kelurahan Wailan merupakan salah satu kelurahan yang terletak di Kecamatan Tomohon Utara Kota Tomohon dengan luas wilayah 450 $\mathrm{ha} / \mathrm{m} 2$ yang terdiri dari 11 (sebelas) lingkungan. Adapun batas-batas kelurahan sebagai berikut:

Sebelah Utara : Kelurahan Kakaskasen II Kecamatan Tomohon Utara Sebelah Selatan : Kelurahan Woloan Kecamatan Tomohon Barat dan Kelurahan Kayawu Kecamatan Tomohon Utara Sebelah Timur : Kelurahan Kakaskasen dan Kakaskasen III Kecamatan Tomohon Utara Sebelah Barat : Kelurahan Kayawu Kecamatan Tomohon Utara.

\section{Keadaan Penduduk}

Total keseluruhan jumlah penduduk yang ada di kelurahan Wailan sebanyak 3173 jiwa. Tabel 1 menunjukkan jumlah penduduk yang ada di Kelurahan Wailan. 
Tabel 1. Jumlah Penduduk Menurut Jenis Kelamin

\begin{tabular}{lccc}
\hline No & $\begin{array}{c}\text { Jenis } \\
\text { Kelamin }\end{array}$ & $\begin{array}{c}\text { Jumlah } \\
\text { Penduduk } \\
\text { (Orang) }\end{array}$ & $\begin{array}{c}\text { Persentase } \\
(\%)\end{array}$ \\
\hline 1. & Laki-laki & 1.629 & 51.00 \\
2. & Perempuan & 1.544 & 49.00 \\
\hline & Jumlah & 3.173 & 100 \\
\hline
\end{tabular}

Sumber: Kantor Kelurahan Wailan, 2014

Tabel 1 menunjukkan jumlah penduduk berjenis kelamin laki-laki sebanyak 1.629 jiwa atau 51.00 persen dan jumlah penduduk berjenis kelamin perempuan sebanyak 1.544 jiwa atau 49.00 persen, yang tersebar dalam 11 (sebelas) lingkungan dengan jumlah kepala keluarga sebanyak 815 kepala keluarga.

\section{Keadaan Sosial dan Budaya}

\section{Pendidikan}

Tingkat pendidikan di Kelurahan Wailan bervariasi mulai dari yang tidak tamat Sekolah Dasar (SD) laki-laki 22 orang dan perempuan 28 orang, tamat Sekolah Dasar (SD) laki-laki 228 orang dan perempuan 235 orang, Sekolah Lanjutan Tingkat Pertama (SLTP) laki-laki 67 orang dan perempuan 48 orang, Sekolah lanjutan tingkat atas (SLTA) laki-laki 98 orang dan perempuan 55 orang, tamat Diploma (D3) laki-laki 9 orang dan perempuan 14 orang, tamat perguruan tinggi yaitu mencakup tamat Strata Satu (S1) laki-laki 26 orang dan perempuan 40 orang, tamat Magister (S2) lakilaki 7 orang dan perempuan 2 orang, tamat Doktor (S3) laki-laki 1 orang.

Tabel 2. Jumlah Penduduk Berdasarkan Tingkat Pendidikan

\begin{tabular}{cccc}
\hline No. & $\begin{array}{c}\text { Tingkat } \\
\text { Pendidikan }\end{array}$ & $\begin{array}{c}\text { Jumlah } \\
(\text { Orang) }\end{array}$ & $\begin{array}{c}\text { Persentase } \\
(\boldsymbol{\%})\end{array}$ \\
\hline 1. & Tidak Tamat & 50 & 56,81 \\
2. & SD & 463 & 52,61 \\
3. & Tamat SD & 115 & 13,06 \\
4. & SLTP & 153 & 17,38 \\
5. & SLTA & 99 & 11,25 \\
& Perguruan & & \\
& Tinggi & & \\
\hline & Jumlah & 880 & 100 \\
\hline
\end{tabular}

Sumber: Kantor Kelurahan Wailan, 2014
Tabel 2 menunjukkan bahwa yang tidak tamat SD sebanyak 50 orang atau $56,81 \%$, tamat SD sebanyak 463 orang atau $52,61 \%$, SLTP Sebanyak 115 orang atau 13,06\%, SLTA sebanyak 153 orang atau $17,38 \%$, dan perguruan tinggi sebanyak 99 orang atau $11,25 \%$.

\section{Agama}

Masyarakat yang ada di Kelurahan Wailan menganut 4 golongan agama. Tabel 3 merupakan gambaran tentang keadaan penduduk menurut golongan agama di Kelurahan Wailan, dapat dilihat pada Tabel 3.

Tabel 3. Keadaan Penduduk menurut Golongan Agama

\begin{tabular}{ccc}
\hline No & Golongan Agama & Jumlah \\
\hline 1. & Islam & 46 \\
2. & Kristen & 2.313 \\
3. & Katholik & 722 \\
4. & Hindu & 4 \\
& & \\
\hline \multicolumn{2}{r}{ Jumlah } & 3,085 \\
\hline
\end{tabular}

Sumber: Kantor Kelurahan Wailan, 2014

Tabel 3 menunjukkan bahwa penduduk yang beragama Islam sebanyak 46 orang, penduduk yang beragama Kristen sebanyak 2.313 orang, penduduk yang beragama katholik sebanyak 722 orang, penduduk yang beragama hindu sebanyak 4 orang. Pada tabel 3 menunjukkan bahwa mayoritas penduduk yang ada di Kelurahan Wailan beragama Kristen.

\section{Deskripsi Kelompok Tani Susuripen Visi dan Misi Kelompok Tani Susuripen}

a. Visi

Untuk mensejahterakan Anggota.

\section{b. Misi}

Menjadikan Kelompok Tani Susuripen yang mandiri menuju kesejahteraan bersama.

\section{Sejarah Singkat terbentuknya Kelompok Tani Susuripen}

Pada bulan Agustus tahun 2004, para petani berkumpul di suatu hamparan di mana ada sebuah pondok kemudian timbullah niat untuk bekerja sama atau dalam bahasa daerah 
Minahasa disebut Mapalus kemudian para anggota Mapalus ini berkeinginan untuk membentuk kelompok tani bertepatan pada saat itu juga ada seorang anggota yang menjabat sebagai lurah Wailan jadi secara langsung ada respon dari pemerintah terlebih khusus bapak lurah untuk membentuk kelompok tani yang diberi nama kelompok tani Susuripen. Susuripen merupakan bahasa daerah Minahasa lebih khusus bahasa Tombulu dalam bahasa Indonesia susuripen memiliki arti lokasi atau kebun yang agak masuk kedalam kemudian dibuatlah berita acara pembentukan kelompok tani kemudian pada bulan September kelompok tani dikukuhkan oleh Pemerintah Kota Tomohon, kelompok tani Susuripen sampai saat ini bukan hanya mengandalkan komoditi padi sawah tetapi juga bercocok tanam tanaman hortikultura.

\section{Karakteristik Responden}

\section{Umur Responden}

Kemampuan bekerja atau melakukan aktifitas secara fisik bahkan cara berpikir seseorang sangat dipengaruhi faktor umur. Demikian juga dengan para petani dalam melakukan pekerjaannya, anggota yang memiliki umur muda tentunya memiliki kondisi fisik yang lebih kuat serta memiliki daya berpikir yang lebih kreatif dibandingkan yang berumur tua. Dari data primer yang diperoleh, usia anggota antara 24 sampai 77 tahun. Komposisi umur responden dalam penelitian ini disajikan pada Tabel 4.

\begin{tabular}{cccc}
$\begin{array}{c}\text { Tabel 4. Distribusi Responden menurut } \\
\text { Umur Anggota Kelompok Tani } \\
\text { Susuripen }\end{array}$ \\
\hline N & Umur & $\begin{array}{c}\text { Jumlah } \\
\text { Responden } \\
\text { (Orang) }\end{array}$ & $\begin{array}{c}\text { Persentas } \\
\text { e } \\
(\%)\end{array}$ \\
\hline o & & 6 & 30 \\
\hline 1. & $20-30$ & 2 & 10 \\
2. & $31-40$ & 6 & 30 \\
3. & $41-50$ & 5 & 25 \\
4. & $51-60$ & 1 & 5 \\
5. & $>60$ & & 100 \\
\hline
\end{tabular}

Sumber: Diolah dari data primer, 2016
Tabel 4 menunjukkan bahwa jumlah responden pada umur 20-30 tahun menunjukkan presentase yaitu sebanyak 6 responden (30\%), selanjutnya berada pada usia 31-40 tahun menunjukkan presentase sebanyak 2 responden (10\%), pada usia 41-50 tahun menunjukkan presentase sebanyak 6 responden $(30 \%)$, pada usia 51-60 tahun menunjukkan presentase sebanyak 5 responden (25\%), usia >61 tahun menunjukkan presentase sebanyak 1 orang $(5 \%)$.

Tabel 5. Distibusi Responden

berdasarkan jenis kelamin anggota kelompok tani susuripen

\begin{tabular}{cccc}
\hline No & $\begin{array}{c}\text { Jenis } \\
\text { Kelamin }\end{array}$ & $\begin{array}{c}\text { Jumlah } \\
\text { Responden } \\
\text { (Orang) }\end{array}$ & $\begin{array}{c}\text { Persentas } \\
\mathbf{e} \\
(\boldsymbol{\%})\end{array}$ \\
\hline 1 & Laki-laki & 13 & 65 \\
2 & $\begin{array}{c}\text { Perempu } \\
\text { an }\end{array}$ & 7 & 35 \\
& & & \\
\hline & Jumlah & 20 & 100
\end{tabular}

Sumber: Diolah dari data primer, 2016

\section{Jenis Kelamin Responden}

Tabel 5. Menunjukkan bahwa jumlah responden yang berjenis kelamin laki-laki lebih banyak dibandingkan perempuan dengan persentase laki-laki sebanyak 65\% (13 orang) dan responden yang berjenis kelamin perempuan menunjukkan persentase sebanyak $35 \%$ (7 orang).

\section{Tingkat Pendidikan Responden}

Peranan pendidikan formal sangat penting dalam usaha peningkatan kualitas seseorang karena berguna dalam pembangunan pribadi serta peningkatan intelektual dan wawasan seseorang. Berdasarkan hasil penelitian, tingkat pendidik responden bervariasi mulai dari tingkat Sekolah Dasar (SD), Sekolah Menegah Pertama (SMP) sampai Sekolah Menengah Atas (SMA)/sederajat. Komposisi tingkat pendidikan responden dalam penelitian ini dapat dilihat pada Tabel 6 . 
Tabel 6. Distribusi Responden menurut

Tingkat Pendidikan Anggota Kelompok Tani Susuripen.

\begin{tabular}{cccc}
\hline No & $\begin{array}{c}\text { Pendidi } \\
\text { kan }\end{array}$ & $\begin{array}{c}\text { Jumlah } \\
\text { Responden } \\
\text { (Orang) }\end{array}$ & $\begin{array}{c}\text { Persentase } \\
(\mathbf{\%})\end{array}$ \\
\hline 1. & SD & 5 & 25 \\
2. & SMP & 9 & 45 \\
3. & SMA & 6 & 30 \\
\hline & Jumlah & 20 & 100 \\
\hline
\end{tabular}

Sumber: Diolah dari data primer, 2016

Tabel 6 menunjukkan distribusi responden menurut tingkat pendidikan SD sebanyak 5 responden (25\%), SMP sebanyak 9 responden (45\%), SMA sebanyak 6 responden $(30 \%)$.

\section{Partisipasi Anggota Pada Kelompok Tani Susuripen}

\section{Partisipasi Anggota Pada Tahap Pembentukan Keputusan}

Partisipasi pembentukkan keputusan pada anggota kelompok tani susuripen dengan mengadakan pertemuan yang dilaksanakan pada hari sabtu setiap minggunya yang mengharuskan seluruh anggota kelompok tani hadir agar kesepakatan yang ingin dicapai dapat tercapai dengan pengambilan keputusan secara mufakat. Partisipasi dalam bentuk keaktifan anggota dalam mengikuti pertemuan sudah cukup baik, dengan melibatkan seluruh anggota dalam setiap kegiatan pengambilan keputusan. Perencanaan kegiatan yang biasanya dilakukan anggota yaitu merencanakan kegiatan penanaman padi sawah, mulai dari penanaman hingga panen dan pasca panen tidak hanya penanaman padi sawah tetapi juga penanaman tanaman hortikultura yaitu rica dan tomat. Selain itu pengambilan keputusan dalam kelompok tani susuripen juga dilakukan untuk mencari solusi dari berbagai masalah pertanian yang dihadapi dengan musyawarah yang dilakukan oleh seluruh anggota kelompok tani susuripen. Dalam penelitian partisipasi pembentukan keputusan ini ada dua sub indikator yang diukur yaitu keaktifan anggota dalam mengikuti pertemuan dan keaktifan dalam memberikan masukkan.

\section{a. Keaktifan dalam mengikuti pertemuan}

Keaktifan dalam hal ini adalah seberapa sering anggota terlibat dalam mengikuti pertemuan kelompok yang dilaksanakan setiap hari sabtu dalam seminggu dalam penelitian ini keaktifan dalam mengikuti pertemuan di ukur selama setahun dimana pertemuan membahas mengenai berbagai kegiatan kelompok tani dimana anggota harus melaksanakan penanaman padi sawah dan penanaman tanaman hortikultura, pelaksanaan penanaman secara mapalus atau gotong royong seluruh anggota bertanggung jawab dalam pelaksanaannya mulai dari persiapan lahan, perawatan tanaman sampai dengan panen hingga pasca panen padi sawah dan tanaman hortikultura.Keaktifan dalam mengikuti pertemuan dapat dilihat pada Table 7. Hasil penelitian ini menunjukkan bahwa $75 \%$ responden (15 orang) memilih sangat aktif anggota yang memilih sangat aktif adalah anggota yang sadar akan statusnya sebagai pengurus kelompok, anggota yang menginginkan terciptanya kekompakkan sesama anggota kelompok dalam melaksanakan kegiatan pertanian, $10 \%$ responden ( 2 orang) memilih aktif adalah anggota yang mengikuti pertemuan agar memahami dan mengetahui halhal yang harus dilakukan dalam penanaman padi sawah, $15 \%$ responden ( 3 orang) memilih kurang aktif dalam mengikuti pertemuan hal ini dikarenakan berbagai kesibukan. Total skor yang diperoleh dari 20 responden pada pertanyaan nomor 1 adalah 52. Angka indeks partisipasi mengenai pertanyaan nomor 1 yaitu: $52 / 60 \times 100=86,6 \%$ sehingga interpretasi nilainya tergolong tinggi. Karena banyak anggota yang terlibat dalam mengikuti pertemuan setiap hari sabtu dalam seminggu.

\section{b. Keaktifan dalam Memberikan Masukan}

Keaktifan dalam hal ini adalah seberapa sering anggota terlibat dalam memberikan masukan pada pertemuan yang dilaksanakan setiap hari sabtu dalam seminggu, penelitian tentang keaktifan dalam memberikan masukan di ukur selama setahun, keaktifan dalam memberikan masukan dapat dilihat pada Tabel 8 . 
Tabel 7. Keaktifan dalam Mengikuti Pertemuan

\begin{tabular}{llcccc}
\hline No & $\begin{array}{c}\text { Tingkat } \\
\text { Partisiasi }\end{array}$ & $\begin{array}{c}\text { Alternatif } \\
\text { Skor }\end{array}$ & $\begin{array}{c}\text { Jumlah Responden } \\
\text { Skor }\end{array}$ & $\begin{array}{c}\text { Persentase } \\
\text { (Orang) }\end{array}$ & $\begin{array}{c}\text { Total } \\
\text { Skor }\end{array}$ \\
\hline 1 & Sangat Aktif & 3 & 15 & 75 & 45 \\
2 & Aktif & 2 & 2 & 10 & 4 \\
3 & Kurang Aktif & 1 & 3 & 15 & 3 \\
\hline & & Jumlah & 20 & 100 & 52 \\
\hline
\end{tabular}

Sumber: Diolah dari Data Primer, 2016

Tabel 8. Keaktifan dalam memberikan masukkan

\begin{tabular}{llcccc}
\hline No & $\begin{array}{c}\text { Tingkat } \\
\text { Partisiasi }\end{array}$ & $\begin{array}{c}\text { Alternatif } \\
\text { Skor }\end{array}$ & $\begin{array}{c}\text { Jumlah Responden } \\
\text { Skor }\end{array}$ & $\begin{array}{c}\text { Persentase } \\
\text { (Orang) }\end{array}$ & $\begin{array}{c}\text { Total } \\
\text { Skor }\end{array}$ \\
\hline 1 & Sangat Aktif & 3 & 8 & 40 & 24 \\
2 & Aktif & 2 & 7 & 35 & 14 \\
3 & Kurang Aktif & 1 & 5 & 25 & 5 \\
\hline & & Jumlah & 20 & 100 & 43 \\
\hline
\end{tabular}

Sumber: Diolah dari Data Primer, 2016

Hasil penelitian ini menunjukkan bahwa $40 \%$ responden ( 8 orang) memilih sangat aktif, anggota yang memilih sangat aktif adalah anggota yang sangat aktif memberikan masukan dalam bentuk pengurusan kelompok, memberi saran dalam hal kehadiran pertemuan kelompok dan saran untuk perkembangan kelompok, 35\% respoden ( 7 orang) memilih aktif, anggota yang memilih aktif adalah anggota yang memberikan masukan tentang keaktifan anggota dalam kegiatan-kegiatan kelompok, 25\% responden (5 orang) memilih kurang aktif hal ini dikarenakan anggota kurang berpengalaman. Total skor yang diperoleh dari 20 responden pada pertanyaan nomor 2 adalah 43. Angka indeks partisipasi mengenai pertanyaan nomor 2 yaitu: $43 / 60 \mathrm{x}$ $100=71,6 \%$ sehingga interpretasi nilainya tergolong tinggi. Karena pada saat pertemuan banyak anggota yang sangat aktif dan aktif dalam memberikan masukan.

\section{Partisipasi Anggota pada Pelaksanaan Kegiatan Kelompok}

Tahap

Partisipasi pelaksanaan kegiatan kelompok tani susuripen selalu diikuti oleh anggota kelompok tani susuripen dengan aktif. Kegiatan kelompok tani susuripen yang dilaksankan secara umum yaitu kegiatan penanaman padi sawah yang dilaksanakan selama 1 sampai 2 kali musim penanaman dalam setahun, penanaman tanaman hortikultura yang dilakukan 1 sampai 5 kali penanaman selama setahun, begitu juga dengan kegiatan panen dan pasca panen padi sawah yang dilaksanakan selama 1 sampai 2 kali dalam setahun, kegiatan panen dan pasca panen tanaman hortikultura yang dilaksanakan 1 sampai 41 Kali dalam setahun untuk tomat 9 kali panen dalam setahun dan untuk cabe 32 kali panen, kegiatan penyuluhan yang didampingi oleh Penyuluh Pertanian Lapangan yang selama setahun 1 sampai 48 kali dilaksanakan penyuluhan dalam setahun, kegiatan dalam memberikan iuran wajib yang pengumpulannya di lakukan 35 sampai 52 kali dalam setahun. Dalam penelitian partisipasi dalam tahap pelaksanaan ada 6 sub indikator yang di ukur yaitu, keaktifan dalam kegiatan penanaman padi sawah, keaktifan dalam penanaman tanaman hortikultura, keaktifan dalam panen dan pasca panen padi sawah, keaktifan dalam panen dan pasca panen tanaman hortikultura, keaktifan dalam mengikuti penyuluhan, dan keaktifan dalam memberikan iuran wajib. 
Tabel 9. Keaktifan dalam Kegiatan Penanaman Padi Sawah

\begin{tabular}{llcccc}
\hline No & $\begin{array}{c}\text { Tingkat } \\
\text { Partisiasi }\end{array}$ & $\begin{array}{c}\text { Alternatif } \\
\text { Skor }\end{array}$ & $\begin{array}{c}\text { Jumlah Responden } \\
\text { Skor }\end{array}$ & $\begin{array}{c}\text { Persentase } \\
\text { (Orang) }\end{array}$ & $\begin{array}{c}\text { Total } \\
\text { Skor }\end{array}$ \\
\hline 1 & Sangat Aktif & 3 & 14 & 70 & 42 \\
2 & Aktif & 2 & 4 & 20 & 8 \\
3 & Kurang Aktif & 1 & 2 & 10 & 2 \\
\hline & & Jumlah & 20 & 100 & 52 \\
\hline
\end{tabular}

Sumber: Diolah dari Data Primer, 2016

\section{c. Keaktifan dalam Kegiatan Penanaman Padi Sawah}

Keaktifan dalam kegiatan penanaman padi sawah adalah seberapa sering anggota terlibat dalam tahap penanaman, dalam hal ini bukan hanya penanaman tetapi juga terlibat dalam pemeliharaan padi sawah, dalam penelitian ini keaktifan di ukur selama 2 musim penanaman dalam setahun, keaktifan dalam kegiatan penanaman padi sawah dapat dilihat pada tabel 9.

Hasil penelitian ini menunjukkan bahwa $70 \%$ responden (14 orang) memilih sangat aktif adalah anggota yang ingin meningkatkan pendapatan, $20 \%$ responden (4 orang) memilih aktif adalah anggota yang berpengalaman dalam bertani, $10 \%$ responden (2 orang) memilih kurang aktif adalah anggota yang memiliki berbagai kesibukan. Total skor yang diperoleh dari 20 responden pada pertanyaan ini adalah 52. Angka indeks partisipasi mengenai pertanyaan nomor 3 yaitu: 52/60 x $100=86,6 \%$ sehingga interpretasi nilainya tergolong tinggi. Karena anggota sangat aktif dalam kegiatan penanaman padi sawah.

\section{a. Keaktifan dalam penanaman tanaman hortikultura.}

Keaktifan dalam kegiatan penanaman tanaman hortikultura adalah seberapa sering anggota terlibat dalam penanaman tanaman hortikultura bukan hanya penanaman saja tetapi juga terlibat dalam merawat tanaman sampai dengan panen hingga pasca panen, tanaman hortikultura yang ditanaman adalah cabe dan tomat dalam penelitian ini keaktifan di ukur sebanyak 4 sampai 5 kali penanaman dalam setahun, keaktifan dalam penanaman tanaman hortikultura dapat dilihat pada tabel 10 .

Hasil penelitian ini menunjukkan bahwa $40 \%$ responden ( 8 orang) memilih sangat aktif adalah anggota yang ingin meningkatkan pendapatan, $20 \%$ responden (4 orang) memilih aktif, $40 \%$ responden (8 orang) memilih kurang aktif adalah mereka yang memiliki berbagai kesibukan. Total skor yang diperoleh dari 20 responden pada pertanyaan nomor 4 adalah 40 . Angka indeks partisipasi mengenai pertanyaan nomor 4 yaitu: $40 / 60 \times 100=66,6 \%$ sehingga interpretasi nilainya tergolong cukup.

\section{b. Keaktifan dalam Panen hingga Pasca Panen Padi Sawah.}

Keaktifan dalam panen hingga pasca panen padi sawah adalah seberapa sering anggota terlibat dalam tahap panen hingga pasca panen padi sawah, pelaksanaan kegiatan panen hingga pasca panen padi sawah dalam penelitian ini di ukur sebanyak 1 sampai 2 kali pemanenan selama setahun untuk padi sawah yang sudah di panen dari lahan setiap anggota kemudian disisihkan $10 \%$ hasil padi sawah dari tiap-tiap anggota untuk dipasarkan ke Bulog, warung atau supermarket terdekat. keaktifan dalam panen dan pasca panen padi sawah dapat dilihat pada tabel 11.

Hasil penelitian ini menunjukkan bahwa $80 \%$ responden (16 orang) memilih sangat aktif adalah anggota yang bersemangat dalam kegiatan pemanenan dan memiliki kesadaran sebagai pengurus kelompok, $15 \%$ responden (3 orang) memilih aktif adalah anggota yang ingin melancarkan kegiatan pertanian, 5\% responden (1 orang) memilih kurang aktif adalah anggota yang terhambat dengan kegiatan lainnya. Total skor yang diperoleh dari 20 responden pada pertanyaan nomor 5 adalah 55. Angka indeks partisipasi mengenai pertanyaan nomor 5 yaitu: $55 / 60 \mathrm{x}$ $100=91,6 \%$ sehingga interpretasi nilainya tergolong tinggi. Karena anggota sangat aktif setiap panen hingga pasca panen padi sawah. 
Tabel 10. Keaktifan dalam penanaman tanaman hortikultura.

\begin{tabular}{llcccc}
\hline No & $\begin{array}{c}\text { Tingkat } \\
\text { Partisiasi }\end{array}$ & $\begin{array}{c}\text { Alternatif } \\
\text { Skor }\end{array}$ & $\begin{array}{c}\text { Jumlah Responden } \\
\text { Skor }\end{array}$ & $\begin{array}{c}\text { Persentase } \\
\text { (Orang) }\end{array}$ & $\begin{array}{c}\text { Total } \\
\text { Skor }\end{array}$ \\
\hline 1 & Sangat Aktif & 3 & 8 & 40 & 24 \\
2 & Aktif & 2 & 4 & 4 & 8 \\
3 & Kurang Aktif & 1 & 8 & 8 & 8 \\
\hline & & Jumlah & 20 & 100 & 40 \\
\hline
\end{tabular}

Sumber: Diolah dari Data Primer, 2016

Tabel 11. Keaktifan dalam Panen hingga Pasca Panen Padi Sawah.

\begin{tabular}{llcccc}
\hline No & \multicolumn{1}{c}{$\begin{array}{c}\text { Tingkat } \\
\text { Partisiasi }\end{array}$} & $\begin{array}{c}\text { Alternatif } \\
\text { Skor }\end{array}$ & $\begin{array}{c}\text { Jumlah Responden } \\
\text { Skor }\end{array}$ & $\begin{array}{c}\text { Persentase } \\
\text { (Orang) }\end{array}$ & $\begin{array}{c}\text { Total } \\
\text { Skor }\end{array}$ \\
\hline 1 & Sangat Aktif & 3 & 16 & 80 & 48 \\
2 & Aktif & 2 & 3 & 15 & 6 \\
3 & Kurang Aktif & 1 & 1 & 5 & 1 \\
\hline & & Jumlah & 20 & 100 & 55 \\
\hline
\end{tabular}

Sumber: Diolah dari Data Primer, 2016

\section{Keaktifan dalam Panen hingga Pasca Panen Tanaman Hortikultura.}

Keaktifan dalam hal ini ada adalah seberapa sering anggota terlibat dalam kegiatan panen hingga pasca panen tanaman hortikultura yaitu cabe dan tomat yang nantinya setelah pasca panen dijual langsung ke pasar beriman tomohon dan fresh mart dalam penelitian ini keaktifan dalam panen dan pasca panen di ukur sebanyak 1 sampai 41 kali pemanenan dalam setahun. Keaktifan dalam panen dan pasca panen tanaman hortikultura dapat dilihat pada tabel 12 .

Hasil penelitian ini menunjukkan bahwa $45 \%$ responden (9 orang) memilih sangat aktif adalah anggota yang ingin menambah penghasilan, memperlancar kegiatan kelompok, $20 \%$ responden (4 orang) memilih aktif, $35 \%$ responden (7 orang) memilih kurang aktif karena berbagai kesibukan lainnya. Total skor yang diperoleh dari 20 responden pada pertanyaan no 6 adalah 42. Angka indeks partisipasi mengenai pertanyaan nomor 6 yaitu: $42 / 60 \times 100=70,0 \%$ sehingga interpretasi nilainya tergolong tinggi. Karena pada saat panen hingga pasca panen tanaman hortikultura anggota sangat aktif dalam pelaksanaannya.

\section{g. Keaktifan dalam Mengikuti Penyuluhan}

Keaktifan dalam hal ini adalah seberapa sering anggota terlibat dalam mengikuti penyuluhan mengenai penyuluhan penanaman padi sawah dan tanaman hortikultura, penyuluhan merawat tanaman padi sawah dan tanaman hortikultura, penyuluhan panen hingga pasca panen padi sawah dan tanaman hortikultura, setiap bulannya anggota mengikuti penyuluhan yang didampingi oleh Penyuluh Pertanian Lapangan (PPL) Kelurahan Wailan dalam sebulan penyuluhan dilaksanakan 3 sampai 4 kali, dalam penelitian ini keaktifan dalam mengikuti penyuluhan yang didampingi oleh PPL di ukur selama setahun. Keaktifan dalam mengikuti penyuluhan dapat dilihat pada tabel 13 .

Hasil penelitian ini menunjukkan bahwa 45\% Responden (9 orang) memilih sangat aktif adalah anggota yang selalu hadir pada saat dilaksanakan penyuluhan dan anggota mengikuti penyuluhan agar dapat mengetahui apa saja yang akan dilakukan dalam kegiatan usahatani, 20\% Responden (4 orang) memilih aktif adalah anggota yang mengikuti penyuluhan untuk menunjang berbagai kegiatan kelompok tani, 35\% Responden (7 orang) memilih kurang aktif adalah anggota yang jarang hadir dalam penyuluhan dikarenakan oleh berbagai kesibukan. Total skor yang diperoleh dari 20 Responden pada pertanyaan no 7 adalah 42. Angka indeks partisipasi mengenai pertanyaan nomor 7 yaitu: 42/60 x $100=70 \%$ sehingga interpretasi nilainya tergolong tinggi. Karena pada saat penyuluhan hampir seluruh anggota terlibat dalam kegiatan penyuluhan. 
Tabel 12. Keaktifan dalam Panen dan Pasca Panen Tanaman Hortikultura

\begin{tabular}{llcccc}
\hline No & $\begin{array}{c}\text { Tingkat } \\
\text { Partisiasi }\end{array}$ & $\begin{array}{c}\text { Alternatif } \\
\text { Skor }\end{array}$ & $\begin{array}{c}\text { Jumlah Responden } \\
\text { Skor }\end{array}$ & $\begin{array}{c}\text { Persentase } \\
\text { (Orang) }\end{array}$ & $\begin{array}{c}\text { Total } \\
\text { Skor }\end{array}$ \\
\hline 1 & Sangat Aktif & 3 & 9 & 45 & 27 \\
2 & Aktif & 2 & 4 & 20 & 8 \\
3 & Kurang Aktif & 1 & 7 & 35 & 7 \\
\hline & & Jumlah & 20 & 100 & 42 \\
\hline
\end{tabular}

Sumber: Diolah dari Data Primer, 2016

Tabel 13. Keaktifan dalam Mengikuti Penyuluhan

\begin{tabular}{llcccc}
\hline No & $\begin{array}{c}\text { Tingkat } \\
\text { Partisiasi }\end{array}$ & $\begin{array}{c}\text { Alternatif } \\
\text { Skor }\end{array}$ & $\begin{array}{c}\text { Jumlah Responden } \\
\text { Skor }\end{array}$ & $\begin{array}{c}\text { Persentase } \\
\text { (Orang) }\end{array}$ & $\begin{array}{c}\text { Total } \\
\text { Skor }\end{array}$ \\
\hline 1 & Sangat Aktif & 3 & 9 & 45 & 27 \\
2 & Aktif & 2 & 4 & 20 & 8 \\
3 & Kurang Aktif & 1 & 7 & 35 & 7 \\
\hline & & Jumlah & 20 & 100 & 42 \\
\hline
\end{tabular}

Sumber: Diolah dari Data Primer, 2016

\section{h. Keaktifan dalam Memberikan Iuran Wajib}

Keaktifan dalam hal ini adalah seberapa sering anggota memberikan iuran wajib sebesar Rp2.000 hingga Rp5.000 yang di kumpul sekali dalam seminggu, yang dipakai untuk berbagai kegiatan kelompok seperti pembelian pupuk, racun untuk tanaman bahkan digunakan untuk natal kelompok tani dalam penelitian ini keaktifan diukur selama setahun, keaktifan dalam memberikan iuran wajib dapat dilihat pada tabel 14 .

Hasil penelitian ini menunjukkan bahwa $80 \%$ responden (16 orang) memilih sangat aktif adalah anggota yang sadar akan kewajibannya dimana mengumpulkan iuran merupakan keharusan yang telah disepakati bersama dan iuran akan digunakan untuk kesejahteraan kelompok, 5\% responden (1 orang) memilih aktif anggota yang mengumpulkan iuran untuk menunjang kegiatan kelompok tani, 15\% responden (3 orang) memilih kurang aktif adalah anggota yang sibuk dengan berbagai kesibukan lainnya sehingga. Total skor yang diperoleh dari 20 Responden pada pertanyaan no 8 adalah 53. Angka indeks partisipasi mengenai pertanyaan nomor 8 yaitu: 53/60 x $100=88,3 \%$ sehingga interpretasi nilainya tergolong tinggi. Karena dalam mengumpulkan iuran wajib anggota sangat aktif dalam memberi.

\section{Partisipasi Anggota Pada Tahap Evaluasi Kegiatan}

Partisipasi evaluasi kegiatan kelompok tani susuripen yaitu memantau kegiatan kelompok dan mengukur berbagai hasil kegiatan usaha tani yang telah dilakukan. Evaluasi yang dilakukan yaitu bermusyawarah mengenai berbagai kekurangan. Selain itu kelompok tani susuripen juga berusaha meningkatkan kualitas usaha tani yang dilaksanakannya. Dalam penelitian partisipasi dalam tahap evaluasi ada 2 sub indikator yang diukur yaitu, keterlibatan dalam pemantauan kegiatan kelompok dan keterlibatan dalam mengukur berbagai hasil kegiatan usaha tani.

\section{i. Keterlibatan dalam Pemantauan Kegiatan Kelompok}

Keterlibatan dalam hal ini adalah seberapa sering anggota terlibat dalam tahap pemantauan kegiatan kelompok, dalam hal ini bukan hanya sekedar memantau tetapi juga berperan aktif dalam berbagai kegiatan kelompok, keterlibatan dalam pemantauan kegiatan kelompok dalam penelitian ini diukur dalam setahun, dapat dilihat pada tabel 15 . 
Tabel 14. Keaktifan dalam Memberikan Iuran Wajib

\begin{tabular}{llcccc}
\hline No & \multicolumn{1}{c}{$\begin{array}{c}\text { Tingkat } \\
\text { Partisiasi }\end{array}$} & $\begin{array}{c}\text { Alternatif } \\
\text { Skor }\end{array}$ & $\begin{array}{c}\text { Jumlah Responden } \\
\text { Skor }\end{array}$ & $\begin{array}{c}\text { Persentase } \\
\text { (Orang) }\end{array}$ & $\begin{array}{c}\text { Total } \\
\text { Skor }\end{array}$ \\
\hline 1 & Sangat Aktif & 3 & 16 & 80 & 48 \\
2 & Aktif & 2 & 1 & 5 & 2 \\
3 & Kurang Aktif & 1 & 3 & 15 & 3 \\
\hline & & Jumlah & 20 & 100 & 53 \\
\hline
\end{tabular}

Sumber: Diolah dari Data Primer, 2016

Tabel 15. Keterlibatan dalam Pemantauan Kegiatan Kelompok

\begin{tabular}{llcccc}
\hline No & $\begin{array}{c}\text { Tingkat } \\
\text { Partisiasi }\end{array}$ & $\begin{array}{c}\text { Alternatif } \\
\text { Skor }\end{array}$ & $\begin{array}{c}\text { Jumlah Responden } \\
\text { Skor }\end{array}$ & $\begin{array}{c}\text { Persentase } \\
\text { (Orang) }\end{array}$ & $\begin{array}{c}\text { Total } \\
\text { Skor }\end{array}$ \\
\hline 1 & Sangat Aktif & 3 & 14 & 70 & 42 \\
2 & Aktif & 2 & 2 & 10 & 4 \\
3 & Kurang Aktif & 1 & 4 & 20 & 4 \\
\hline & & Jumlah & 20 & 100 & 50 \\
\hline
\end{tabular}

Sumber: Diolah dari Data Primer, 2016

Hasil penelitian ini menunjukkan bahwa $70 \%$ responden (14 orang) memilih sangat aktif adalah anggota yang memiliki tugas sebagai pengurus kelompok dan selalu terlibat dalam memberikan masukan dalam memantau kegiatan kelompok untuk kesejahteraan anggota dalam meningkatkan hasil panen serta pendapatan anggota, $10 \%$ responden ( 2 orang) memilih aktif adalah anggota yang berpengalaman dalam memberikan masukan, $20 \%$ responden (4 orang) memilih kurang aktif adalah anggota yang kurang berpengalaman dalam pemantauan kegiatan kelompok. Angka indeks partisipasi mengenai pertanyaan nomor 9 yaitu: $50 / 60$ x $100=83,3 \%$ sehingga interpretasi nilainya tergolong tinggi. Karena anggota sangat aktif dalam memantau kegiatan kelompok.

j. Keterlibatan dalam Mengukur Berbagai Hasil Kegiatan Usaha Tani

Keterlibatan dalam hal ini adalah seberapa sering anggota terlibat dalam tahap mengukur berbagai hasil kegiatan usaha tani dalam hal ini bukan saja mengukur tetapi juga berperan aktif dalam pemanfaatan berbagai hasil kegiatan usaha tani untuk kebutuhan hidup sehari-hari. Keterlibatan dalam mengukur berbagai hasil kegiatan usaha tani dapat dilihat pada tabel 16.

Hasil penelitian ini menunjukkan bahwa $75 \%$ responden (15 orang) memilih sangat aktif adalah anggota yang ingin mengetahui apa saja yang dicapai dalam usaha tani dan terlibat dalam memberikan masukan karena merupakan petani berpengalaman, $25 \%$ (5 orang) memilih kurang aktif adalah anggota yang kurang berpengalaman dalam kegiatan usaha tani dan memiliki berbagai kesibukan lainnya. Angka indeks partisipasi mengenai pertanyaan nomor 10 yaitu: $50 / 60 x \quad 100=83,3 \%$ sehingga interpretasi nilainya tergolong tinggi. Karena anggota sangat aktif dalam mengukur berbagai hasil kegiatan usaha tani.

Tabel 16. Keterlibatan dalam Mengukur Berbagai Hasil Kegiatan Usaha Tani

\begin{tabular}{llcccc}
\hline \multirow{2}{*}{ No } & $\begin{array}{c}\text { Tingkat } \\
\text { Partisipasi }\end{array}$ & $\begin{array}{c}\text { Alternatif } \\
\text { Skor }\end{array}$ & $\begin{array}{c}\text { Jumlah Responden } \\
\text { Skor } \\
\text { (Orang) }\end{array}$ & $\begin{array}{c}\text { Persentase } \\
(\%)\end{array}$ & $\begin{array}{c}\text { Total } \\
\text { Skor }\end{array}$ \\
\hline 1 & Sangat Aktif & 3 & 15 & 75 & 45 \\
2 & Aktif & 2 & - & - & - \\
3 & Kurang Aktif & 1 & 5 & 25 & 5 \\
\hline & & Jumlah & 20 & 100 & 50 \\
\hline
\end{tabular}

Sumber: Diolah dari Data Primer, 2016 


\section{Tabel 17. Rekapitulasi Jumlah Skor Pengambilan Data, dan Interpretasi Partisipasi Anggota Pada Kelompok Tani Susuripen.}

\begin{tabular}{|c|c|c|c|c|}
\hline No & Pertanyaan & $\begin{array}{l}\text { Total } \\
\text { Skor }\end{array}$ & $\begin{array}{c}\text { Indeks } \\
\text { Partispasi }\end{array}$ & Interpretasi \\
\hline 1 & Keaktifan dalam mengikuti pertemuan & 52 & 86,6 & Tinggi \\
\hline 2 & Keaktifan dalam memberikan masukan & 43 & 71,6 & Tinggi \\
\hline 3 & $\begin{array}{l}\text { Keaktifan dalam kegiatan penanaman padi } \\
\text { sawah }\end{array}$ & 52 & 86,6 & Tinggi \\
\hline 4 & $\begin{array}{l}\text { Keaktifan dalam kegiatan penanaman } \\
\text { Tanaman hortikultura }\end{array}$ & 40 & 66,6 & Cukup \\
\hline 5 & $\begin{array}{l}\text { Keaktifan dalam panen dan pasca Panen padi } \\
\text { sawah }\end{array}$ & 55 & 91,6 & Tinggi \\
\hline 6 & $\begin{array}{l}\text { keaktifan dalam panen dan pasca Panen } \\
\text { tanaman hortikultura }\end{array}$ & 42 & 70,0 & Tinggi \\
\hline 7 & Keaktifan dalam mengikuti penyuluhan & 42 & 70,0 & Tinggi \\
\hline 8 & keaktifan dalam memberikan iuran wajib & 53 & 88,3 & Tinggi \\
\hline 9 & $\begin{array}{l}\text { Keterlibatan dalam pemantauan kegiatan } \\
\text { kelompok }\end{array}$ & 50 & 83,3 & Tinggi \\
\hline 10 & $\begin{array}{l}\text { Keterlibatan dalam mengukur Berbagai hasil } \\
\text { kegiatan usaha Tani }\end{array}$ & 50 & 83,3 & Tinggi \\
\hline
\end{tabular}

Sumber: Diolah dari Data Primer, 2016

Tabel 17 menunjukkan bahwa terdapat 10 indikator partisipasi anggota pada kelompok tani susuripen dimana pertanyaan ke 5 mendapat indeks tertinggi yaitu 91,6\%, karena anggota kelompok tani susuripen sangat aktif pada setiap panen dan pasca panen padi sawah. Sedangkan pertanyaan 1 mendapat indeks partisipasi $86,6 \%$, pertanyaan 2 mendapat indeks partisipasi $71,6 \%$, pertanyaan 3 mendapat indeks partisipasi $86,6 \%$, pertanyaan ke 4 mendapat indeks partisipasi 66,6\%, pertanyaan ke 5 mendapat indeks partisipasi $91,6 \%$, pertanyaan ke 6 mendapat indeks partisipasi $70,0 \%$, pertanyaan ke 7 mendapat indeks partisipasi $70,0 \%$, pertanyaan ke 8 mendapat indeks partisipasi $88,3 \%$, pertanyaan ke 9 mendapat indeks partisipasi 83,3\%, pertanyaan ke 10 mendapat indeks partisipasi 83,3\% hampir semuanya mendapat interpretasi tinggi. Pertanyaan ke 4 mendapat interpretasi cukup karena berada di 66,6\%. Dan pertanyaan $1,2,3,5,6,7,8,9,10$ mendapat interpretasi tinggi karena berada di atas $66,6 \%$. Untuk mengetahui partisipasi anggota pada kelompok tani susuripen di kelurahan wailan maka perlu di hitung jumlah keseluruhan skor. Dimana hasil penelitian ini skor mencapai 479. Pada penelitian ini jumlah skor ideal atau skor tertinggi yaitu 600 dan jumlah skor terendah adalah 200. Dari data yang dihimpun sebanyak 10 pertanyaan yang diajukan kepada 20 responden maka diperoleh total skor 479. Secara persentase angka indeks partisipasi anggota pada kelompok tani susuripen di kelurahan wailan kecamatan tomohon utara terletak pada.

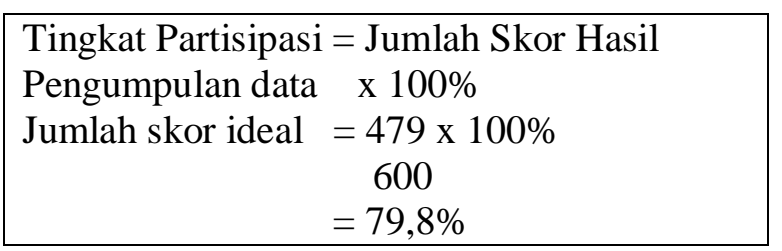

Berdasarkan hasil analisis menggunakan skala likert maka dapat diketahui bahwa angka indeks partisipasi anggota pada kelompok tani susuripen berada pada titik 79,8\% dan tergolong tinggi. Kesimpulan secara keseluruhan dari penelitian ini tergambar dalam rekapitulasi jumlah skor partisipasi anggota pada kelompok tani susuripen. Partisipasi pada kegiatan lainnya semuanya tergolong tinggi. Kecuali keaktifan dalam kegiatan penanaman tanaman hortikultura yang tergolong cukup. 


\section{KESIMPULAN DAN SARAN}

\section{Kesimpulan}

1. Berdasarkan hasil penelitian telah diketahui bahwa partisipasi anggota pada tahap perencanaan, tahap pelaksanaan dan tahap evaluasi kelompok tani Susuripen tergolong tinggi dalam interpretasinya pada kelompok tani Susuripen di Kelurahan Wailan Kecamatan Tomohon Utara Kota Tomohon.

2. Analisis menggunakan skala likert di temukan bahwa angka indeks partisipasi anggota pada kelompok tani Susuripen di Kelurahan Wailan Kecamatan Tomohon Utara Kota Tomohon berada pada titik $79,8 \%$ dan tergolong tinggi.

\section{Saran \\ Pemerintah maupun masyarakat} setempat lebih mengiatkan partisipasi anggota pada kelompok tani Susuripen di Kelurahan Wailan Kecamatan Tomohon Utara Kota Tomohon karena hal tersebut merupakan pelaku utama dan pelaku usaha dalam pembangunan ketahanan pangan.

\section{DAFTAR PUSTAKA}

Amanah, Siti dan Farmayanti, Narni. 2014. Pemberdayaan Sosial Petani-Nelayan, Keunikan Agroekosistem dan Daya Saing. Penerbit Yayasan Pustaka Obor Indonesia. Jakarta.

Anantanyu, S. 2009. Partisipasi Petani dalam Meningkatkan Kapasitas Kelembagaan Kelompok Petani (Kasus di Provinsi Jawa Tengah). Disertasi pada Institut Pertanian Bogor.http://agribisnis.fp.uns.ac.id/wpcontent/ uploads/2013/10/05-Sapja-Anantanyu-

Kelembagaan-Petani-Peran-Dan-Strategi-

Pengembangan-Kapasitasnya.pdf (diakses pada 13 maret 2016).

Arnstein, Sherry R. 2007. A Ladder of Citizen Participation.Http://www.Lithgrow-

Schmidt.dk/sherry-arnstein/ladder-of-citizenParticipation.pdf. (diakses 14 Februari 2016).

Aprillia, dkk. 2015. Pembangunan Berbasis Masyarakat. Penerbit Alfabeta. Bandung.

Chamala, R.S., 1995. Overview of Participative Action Approaches in Australian Land and Water Management. Dalam Chamala, S. and Keith, K. (eds), 1995. Participative Approaches for Landcare:
Perspective, Policies, Program. Brisbane : Australian Academic Press.

Hikmat, H., 2004. Strategi Pemberdayaan Masyarakat. Penerbit Humoniora, Bandung.

Khairuddin, 2000. Pembangunan Masyarakat., Tinjauan Aspek: Sosiologi, Ekonomi dan Perencanaan. Liberty, Yogyakarta.

Makeham, J.P. dan R.L. Malcom, 1991. Manajemen Usahatani Daerah Tropis. Jakarta: LP3ES.

Nuryanti dan Swastika. 2011. Peran Kelompok Tani dalam Penerapan TeknologiPertanian.http://pse.litbang.deptan.g o.id/ind/pdffiles/FAE29-2d.pdf diakses pada 03 februari 2016.

Ramli. 2010. "Pentingnya Koordinasi, Integrasi, Sinkronisasi dan Sinergitas antar SKPD dalam Proses Implementasi Program Agropolitan dan Agromerinepolitan di Sumatera Utara". Pembangunan Perdesaan dalam Rangka Peningkatan Kesejahteraan Masyarakat. Pemikiran Guru Besar Perguruan Tinggi Badan Hukum Milik Negara. Bogor: IPB Press.

Riduwan. 2012. Rumus dan data dalam analisis statistika. Penerbit alphabet. Bandung.

Sastropoetra, R,A., Santoso (1988), Partisipasi, Komunikasi, Persuasi, dan disiplin dalam Pembangunan Nasional, Bandung: PT. Alumni.

Septiany, Irma. 2012. Partisipasi Masyarakat dalam Implementasi Program Nasional Pemberdayaan Masyarakat (PNPM) Mandiri Perkotaan dengan penggunaan model CLEAR di Kelurahan Kaliabang Tengah, Kecamatan Bekasi Utara, Kota Bekasi. Skripsi Jurusan Ilmu Administrasi Negara. Fakultas Ilmu Sosial dan Ilmu Politik. Univesitas Indonesia. Depok.

Soetriono, Anik Suwandari dan Rijanto, 2006. Pengantar Ilmu Pertanian. Malang: Bayumedia Publishing.

Sumardjo, M.A. Chozin dan Ali Khomsan. 2010. "Transformasi Perencanaan Pembangunan Perdesaan dengan Beragam Tipologi”. Pembangunan Perdesaan dalam Rangka Peningkatan Kesejahteraan Masyarakat. Pemikiran Guru Besar Perguruan Tinggi Badan Hukum Milik Negara. Bogor: IPB Press.

Uphoff, Norman Thomas. 1986. Local Institutional Development: An Analytical Sourcebook With Cases. Kumarian Press. http://agribisnis.fp.uns.ac.id/wpcontent/uploads/2013/10/05-SapjaAnantanyu-Kelembagaan-Petani-Peran-DanStrategi-Pengembangan-Kapasitasnya.pdf. (Diakses pada 13 maret 2016) 